\title{
Gender and Sexuality: The Discursive Limits of 'Equality' in Higher
}

\section{Education}

\section{Liz Morrish (Nottingham Trent University) and Helen Sauntson (University of Birmingham)}

\begin{abstract}
This special issue sets out to investigate a number of areas of concern, regarding gender and sexuality, which are identifiable in the current British higher education environment. We argue that current dominant 'neoliberal' discourses, which emphasise the commodification of higher education in the UK, function to set limits upon 'equality'. While these discourses often suggest a widening of opportunities within higher education, with an emphasis upon unlimited individual freedom and choice, the lived experience can be rather different for women and sexual minorities. This issue explores the impact such discourses are having upon gender and sexuality identities and practices in the academy.
\end{abstract}

\section{Keywords}

Neoliberalism, managerialism, discourse, gender, equality

\section{Neoliberal discourses in the academy: values in crisis?}

This collection of papers was generated by a seminar series which took place at the University of Birmingham in the spring of 2009. This journal has already published contributions on the managerialist and neoliberal turn in British and Australian universities (e.g. Canaan 2005; Davies and Bendix Petersen 2005; Rutherford 2005; Welch 2006; 
Wright 2004), and we now present a perspective from some leading neoliberal critics within the UK academy.

What is striking, from the literature and the seminar discussions which took place in Birmingham in the Spring of 2009, is the large measure of agreement that managerialist and neoliberal discourses are injurious to the purpose and functioning of universities as they are conceived of by the people who work and study in them. Academics are being asked to sustain a contradiction between the set of values embodied by neoliberalism (discussed below) and traditional intellectual values more widely held by frontline academics. The tensions between these two sets of values also create particular issues around gender and sexuality. Neoliberal critics such as Duggan (2003) believe a key project of neoliberalism is the re/organization of human activities and relationships along unequal lines, whilst simultaneously disguising this organization. We believe this is a topic which needs to be discussed as extensively and as internationally as possible, and the contributions in this special issue extend beyond universities in the UK.

\section{What is neoliberalism?}

Harvey (2005: 3) provides a useful working definition of neoliberalism:

Neoliberalism is in the first instance a theory of political economic practice that proposes that human well-being can best be advanced by liberating individual entrepreneurial freedoms and skills within an institutional framework characterized by strong private property rights, free markets, and free trade. The role of the state is to create and preserve an institutional framework appropriate to such practices. 
Harvey argues that this institutional framework has now become hegemonic and has extended beyond purely economic enterprises into many public service institutions such as health care, public transport and education.

Since the historic events of September $11^{\text {th }} 2001$ research has appeared which has attempted to set neoliberal policy and thought in its historical and cultural and geo-political context (Duggan 2003; Harvey 2005; Ong 2006). Of these texts, Duggan goes furthest in interrogating the nature of equality regarding gender and sexual identity in the neoliberal state. Her point is that institutions and the state apparatus enforce homogenisation and they preclude any other response than incorporation and erasure of difference. We posit that this argument is applicable to the current situation in much of British higher education and subsequent papers in this issue go some way to corroborating this claim.

Duggan identifies an essential characteristic of neoliberalism as the upward redistribution of resources (Duggan 2003: ix). In slightly stronger terms, Harvey (2005: 11-31) claims the ultimate goal of neoliberalism is the restoration of class power having overtaken 'embedded liberalism', or interventionist Keynesian economics where entrepreneurial and corporate activities were regulated and constrained. Another cornerstone of regimes that follow a neoliberal logic is the emphasis on personal responsibility (Ong 2006:14), and we see citizens being exhorted to be self-managing, selfenterprising individuals in health, education, and other professions. This is what Inoue (2007) terms a 'neoliberal governmentality' (originally a Foucauldian term): a strategy of government that requires the subject to believe they are free and responsible for the outcomes of their 'free' choices. 'Third Way' politics stresses responsibility at the community level and the requirement for individuals to be responsible for themselves. As 
Ong writes, 'the argument is that neoliberalism goes further than just an economic doctrine. It is an extremely malleable technology of governing' (Ong 2006:14). This has been so successful in its global reach that, according to Duggan, (2003: xiii) the process of neoliberalism has now exceeded the range of democratic accountability in the U.S. and the rest of the world. This has happened as neoliberal policies have been put in place to sustain the interests of capitalist "free" markets and multi-national corporations, while simultaneously shrinking the size of the public sector.

\section{Climate change? Neoliberalism in universities}

Most apparent to those who work within the academy has been the emergence of a management that appears to place economic rationalism at the core of its operating philosophy. Harvey (2005: 60) records that strict rules of financial accountability started to be inflicted on U.K. universities by Thatcher's Conservative government of the 1980s which imposed neoliberal reforms on institutions that were ill-suited to them. Universities were encouraged to reposition themselves as simulacra of business and to adopt practices traditionally associated with profit-making organizations such as: annual appraisals, audits of teaching hours, transparency reviews of work practices, peer teaching evaluation, teaching quality and research audits. Indeed, this association between university and business practices cemented itself so fully in the governmental mind that U.K. universities have now become the provenance of the Department for Business, Innovation and Skills. The fact that there is no mention of education in its title is surely not a coincidence.

Harvey (2005) points out that neoliberal institutions open up new fields for capital accumulation. Over the last decade across the U.K. higher education sector, we have seen 
the privatization and commodification of staff and student services. This financialization has created new opportunities for stripping students of their cash. Student halls of residence have been sold off or 'student villages' have been built by Private Finance Initiatives and rented to students for profit. Universities routinely charge for membership of sports facilities. Graduation is no longer an austere academic rite of passage, but is often as garlanded as a celebrity wedding. Departments have been replaced by 'cost centres' headed by 'team leaders' whose duties resemble those of accountants rather than academics. Many universities have been restructured to encompass colleges, but as Johnson points out, these are not the cooperative 'gentlemanly spaces' of his time at Cambridge; these are instead 'a grotesque, lying parody of the collegiate principle' (Johnson 2008: 285). Since the profit motive has been seen as the only priority, economies inevitably fall on practices that attract income - the teaching and research functions of the university (Davies and Bendix Petersen 2005: 88). Management and 'customer service' are enhanced and funding is shifted to administrators who have an auditing rather than a support function. Those who work within these new structures are aware of an alienation and evacuation of academic values. This new climate has been explored in a number of recent works (e.g. Canaan and Shumar 2008; Evans 2005).

A degree of shock greeted the pronouncement in August 2008 by Philip Esler (Head of Research Councils U.K.) that '(R)esearch in itself creates no benefit to anyone. A published paper that no one reads does not advance knowledge or understanding' (Esler 2008). These governmental ciphers are already laying the groundwork for another major attack on academic values and culture. Their argument contends that researchers must 
exploit results (at the time of writing, the current buzzword is 'impact') where appropriate, in order to secure social and economic return to the U.K.

Equally worrying is a comment from Steve Smith, Vice Chancellor of Exeter University and Chair of the Board of the 1994 Group of smaller research-intensive universities, reported in the Times Higher Education Supplement. Smith says that he does not think the arts and humanities have made the case for continued public support for research (Gill 2009). Indeed, one of the more depressing comments to emerge at the University of Birmingham seminar series was from a participant who predicted a future of just ten years for humanities in British universities. This is not an unlikely scenario when we see the recent closure of departments of modern languages, linguistics and cultural studies at U.K institutions.

This kind of capriciousness and short-termism is all too familiar, and it makes planning research, and indeed careers, in universities a high-risk activity. Harvey (2005: 162) identifies another characteristic of the neoliberal academy - the management and manipulation of crises. Anyone who has worked in U.K. universities since 1981 will recognise that their careers have unfolded in an era of constant crisis, accompanied by urgent calls for 'change', 'efficiency' and 'modernisation' to forestall further crisis. To now claim, in 2010-11, that the current economic situation has brought about an exceptional funding emergency in universities is to stretch academics' tolerance for such accounts, and to make a mockery of previous claims that crisis is averted when employees are flexible, responsive and efficient, as many of us have been for several decades.

In order to make sure that notions of efficiency take centre stage for academics, structures of neoliberal govermentality have been implemented to control access to resources. In the 
U.K., Research Assessment Exercises (RAE) have taken place every six years since 1992. ${ }^{1}$ Research money has been 'earned' when research units submit their profiles and 'outputs' are ranked according to a scale of national or international excellence. This imperfect and sometimes erratic system ensures that there is redistribution of resources and accumulation by dispossession (Harvey 2005: 159).

There has been a concomitant impact on student experience in that students have been constructed both materially (through a regime of tuition fees) and discursively as consumers, with choices and entitlements. As Molesworth, Nixon and Scullion (2010) have documented, students who pay fees imagine themselves in different ways from their grant-bearing predecessors, and expect a good level of 'customer service'. (Johnson (2008: 285 ) writes that ' $T$ he teacher-student relation is redefined in terms of producer-consumer relations with major effects on how pedagogies are conceptualized, evaluated and practised'.

\section{Neoliberalism and the managerial turn in UK universities}

A widely-held perception by some university managers appears to be that their skills are generic, and that running a gym and running a university require a similar approach. No knowledge of, or sympathy with, the enterprise is required - in fact this may compromise decision-making through 'vested interests'. We add to this that managerialist institutions display an obsession with auditing and quantification of 'performance', 'goals' and 'targets'.

'Individualism' is prescribed, but only when acquiescent to managerial commands. This neoliberal principle underpins many of the human resources management models now 
in operation in universities which prioritise the advancement of the ultra-compliant employee. 'Exceptional' job performance very often masquerades as 'expected job performance', because, as Davies and Bendix Petersen (2005: 89) note 'workers are compelled never to rest', and the worker becomes 'busier and busier.... unable to see quite what it is that drives them'. The aim of this policy is to ensure that the traditional autonomy of academics within the university is subdued in the interests, however temporary, erratic and self-defeating, of managerial behests. Johnson notes this is perverse for a system which claims to celebrate virtues of freedom, choice and diversity. We would add 'democracy' to that list in view of our recent seminar discussions. It is ironic that in institutions which teach about democracy, so little of it is practiced within their own walls. Neoliberal institutions, as Harvey points out (2005: 66), are hostile to democracy. It is seen as an unaffordable luxury, kept at bay by the imagined state of constant crisis and financial exigency.

\section{Discursive creation of consent}

As discussed above, there is a clear link between neoliberalism and managerialism - the latter obscures the pervasive power of the former and of the institution itself. Administrators have mastered these discourses and demand to be spoken to in their own language by academics who are required to justify their working practices on a frequent basis. A characteristic of neoliberal discourse is that it disguises its own negative impact and so forestalls resistance (Davies and Bendix Petersen 2005: 85). A frequently-cited example would be the way work overload is individualised as 'unable to manage 
workload'. The academic is positioned as culpable and failure to cope is attributed to failure of the individual to make the right 'choices'.

Fairclough (1995: 91) recognises that regimes coerce via a 'technologization of discourse' which he defines as the use of discourse to regulate others, and control access to power. Chiefly, in university managerial discourse, we see the employment of abstract nouns with shape-shifting definitions. These have been termed by Urciuoli (2000) as Strategically Deployable Shifters (SDS). Because SDSs are multi-functional and polysemic, they are not always the sites of overt struggle. University mission statements (Sauntson and Morrish 2010) and internal communications are almost entirely made up of slippery, semantically vague usages, e.g. quality, excellence, teaching and learning, skills. More pernicious has been the way in which the lexical item 'research' has been co-opted on the force of its polysemicity - all academics aspire to research, and it has different meanings for different scholars. It is precisely because academics invest their identities in their research that makes it a good candidate for regulating their behaviour. For university managers, 'research' has been commodified and brought into the realm of the calculable; legitimate only insofar as we recognize artificially imposed 'performance indicators' which are the new hegemony. One's status as an authentic academic, and even what qualifies as work, is redefined by what is marketable and profitable to the corporation.

There is slippage between managerial and academic discourses as academics struggle to find self-worth by measuring achievement in terms set by the institution. Davies and Bendix Petersen's view is that neoliberal discourse is totalizing and those who refuse its penetration will not survive (2005: 82). The subject is totally formed by the 
discourse which they are compelled to cite. For example, which British academic has not disparaged the RAE, and then rejoiced when a book is published in time for the audit?

Canaan (this issue) asks 'why do we keep going along with it?' and suggests that the answer is because the carrot of self-actualization is dangled before academics and their compliance is ensured with the stick of regulation. QAA, RAE, benchmarking etc. all render academics auditable, and allow the imposition of a neoliberal governmentality which works through a destabilization of established academic practices. As it never stands still, we are impelled to go through permanent revolution, so that no practices ever fully establish themselves or achieve legitimacy. The 'second order' activities of audit take over and construct our very beings as academics. Our professional lives are dominated by the need to provide discursive evidence that we are compliant with the regime.

\section{Impact of neoliberalism on gender and sexuality in the academy}

The relationship between neoliberalism and gender and sexuality within higher education is one which has, to date, received little attention, although there have been more general discussions of neoliberalism and gender (e.g. Duggan 2003). Harvey (2005) discusses how the neoliberal system emphasises personal responsibility so the state can disclaim responsibility for the welfare of the population. Therefore, if women (and indeed other social groups) feel disempowered, it is their own fault and not the fault of society. Harvey also refers to the 'increasing feminization of poverty' (2005: 202), noting that the neoliberal process of accumulation by dispossession has particularly negative effects for women, and indeed anyone who is already at an economic disadvantage in society. The effects on lower-class and non-white women can be particularly devastating under a 
neoliberal regime. Neoliberalism is also characterised by very particular and constrained conceptions of 'the family' (i.e. two-parent, heterosexual, married) and some have argued (e.g. Duggan 2003) that this constitutes an assault on both women's and gay rights by marginalising alternative family units. Interestingly, neoliberal discourse often contains specific references to 'equal opportunities' - indeed, 'equality and diversity' policies are now commonplace in many institutions. However, these policies are frequently undermined by people's lived experiences. Duggan (2003) refers to neoliberal equal opportunities discourses as 'strategic alliances' which function to promote an ideology of the neoliberal institution as embracing social and cultural diversity and offering equality of opportunity for all, thus protecting them from criticism and masking the inequalities which routinely occur within such institutions. When the issue of inequalities around race, gender or sexuality are raised, they are often then dismissed as cultural, private or trivial (Duggan 2003). Davies and Saltmarsh (2007) similarly note, specifically in relation to literacy practices in educational contexts, that there is an intensification of gender differences taking place despite the neoliberal rhetoric that dismisses the relevance of such differences. In relation to sexuality, Duggan argues that gay rights groups themselves have now adopted a predominantly neoliberal discourse characterised by corporate decision-making models. Her analysis of the Human Rights Campaign in the USA (a gay civil rights group) is one which charges them with having broken with a progressive agenda, in favour of the more conservative politics of assimilation. It is primarily privileged gay men who accrue the most power within these groups and, as a result, the groups have become increasingly less representative and less unified. Duggan refers to this as the "new homonormativity', represented by an increasingly white, gay male, moneyed elite. 
A key question addressed in this issue is whether neoliberal practices reinforce gender inequality in universities. We frequently find in universities that pastoral and administrative work are not equally distributed among men and women academic staff, and neither are they of equal value in terms of academic currency. In fact, in very hierarchised neoliberal organisations such as universities, only a small subset of behaviours is routinely recognised and rewarded. What qualifies as valuable or authentic work often lies within the realm of the easily calculable, but is not necessarily valuable to students or to the advancement of knowledge. Holmes (2006) has suggested that in the workplace generally, but also in the academy, women do more 'relational practice', defined as work which may be read as 'off task' but nevertheless involves the emotional work of social emollient and serves to keep individuals on task.

Johnson (2008) remarks that gender is 'a deep-seated organising principle' in academic and other institutions, determining positions in hierarchies of status and pay, specifying rules of speech and silence and, importantly, setting the terms of 'emotion management' of anger, fear and shame and their permitted expression. This suggests that in so far as neoliberal reformers aim for 'equal opportunities', they fail adequately to appreciate what gender equality might actually mean and how deep reform must reach into everyday practices. This diversification of women's work, and the constraints of how to perform intelligibly as a female academic also means that women may find themselves in a particularly pernicious neoliberal trap. Equal opportunity is redefined in universities as 'making the right choices' i.e. to do research, and to do a particular type of research which is imbued with the currency for personal advancement. At the time of writing, such research involves that which brings with it external funding and which carries very 
narrowly, metrically-defined indicators of 'impact'. Lynch (2006) notes an increasingly disturbing practice in universities of devaluing and trivialising research, and indeed education in any form, which is seen as having no market value. At present, critical research on gender and sexuality does not tend to attract much external funding because of wider social discriminatory ideologies and practices. So the academic who wants to advance their career may shy away from such research. And if academics do choose to go ahead with such research, then it is their own fault if this does not contribute to their career advancement or status. Ong (2006: 16) recognises the notion of exception, or exclusion from neoliberalism; if you are not self-governing and competitive, you may be excluded. Thus, any perceived lack of equality based on gender and/or sexuality can be easily attributable to the individual's own choices rather than to the structures operating within the institution.

Lynch notes that the introduction of league tables in higher education (a typically neoliberal practice) has played a part in developing an increasing bias against the arts, humanities and many social sciences in European universities. In discussing a report on Irish universities, Building Ireland's Knowledge Economy, Lynch (2006: 6) observes that 'the development of society is equated with economic development and the latter is focused primarily on science and technology'. These are traditionally male-dominated areas of the curriculum, therefore a developing bias against arts and humanities necessarily entails a bias against the women academics who constitute a larger percentage of the workforce in those subject areas. Canaan and Shumar (2008) similarly observe an undervaluing and increasing 'ghettoization' of the arts and humanities. Furthermore, many institutions have witnessed a struggle to keep open overtly 'critical' programmes, such as 
Women's Studies, Gender Studies and Queer Studies. ${ }^{2}$ These programmes clearly exist and function to further the rights of women, LGBTQ people, non-white ethnic groups etc. The closure of such programmes is invariably justified by universities in economic terms. These programmes, which tend to be populated by large numbers of women students and delivered by a significant proportion of women teaching staff, contribute to a genuine sense of inclusiveness.

At a more interactional level, previous research on gendered discourses (e.g. Baxter 2003; Coates 1996; 2003; Sunderland 2004) has found evidence of men repeatedly performing discourses of hegemonic and 'conservative masculinity' (Connell 1995). It could be argued (Canaan, this issue) that the discourses of conservative masculinity share the most similarities with discourses of neoliberalism, with both placing an emphasis upon competitiveness, intellectual prowess and financial, professional and academic success. Connell also notes that a further necessary component of conservative masculinity is the subordination of women, and of men who are seen as less successful. Whilst women may be able to perform these discourses of masculinity by accessing the linguistic resources through which they are enacted, this risks making their gender 'unintelligible' (Butler $1990 ; 2004$ ) and therefore subject to symbolic (and sometimes physical) violence and erasure. For a biological woman to adopt any recognisable discourse of masculinity is, therefore, risky. However, performing traditional, dominant, hegemonic discourses of femininity is also not desirable, as these discourses are usually equated with a lack of social and economic power, especially in neoliberal contexts. The values embedded within dominant discourses of femininity (e.g. collaboration, orientation towards consensus, emotional involvement and intelligence) are often directly at odds with the typical 
neoliberal values of competitiveness and individualism. Many of the discussions which took place during the seminar series, (and which, from our experience, seem to take place on a regular basis in our everyday working lives) reflected on these discursive tensions and contradictions in relation to gender. These tensions seemed even more acute for those who identify as 'non-normative' in some way, either in terms of their gender, sexuality or race. For these people, performing dominant discourses of femininity is not experienced as something familiar or comfortable even outside neoliberal contexts.

These interactional tensions probably contribute to the wider structural problems with gender in universities discussed by Evans (this issue). Evans argues that neoliberal discourse and institutions (especially elite institutions) have produced a new kind of compliant and conformist female academic who completely accepts the new values of the university (i.e. the values of the marketplace and models of social action based on enterprise). The demand that the academic should engage with the economic forces visited upon the university have also produced a new labouring self, or as Goodall (1995: 109) calls it, the overly bureaucratized self, who is unrelentingly positive, engaged in academic entrepreneurship and accepting of existing hierarchies. This demands a negotiation with the institution which is gendered. Davies and Bendix-Petersen in their invocation of the privatisation of difference, and also other authors in this issue (Evans, Canaan), argue that women analyse difficulties as failings of the individual, rather than deficiencies in the institution. The latter become inadmissible, just as anger with institutional values becomes pathologized. Advancement through the hierarchy of the university is available only to compliant 'good girls'. In this way, gender discrimination is no longer overt and categorical, but covert and realised in pressure to conform to the 'feminine ideal'. For men, 
greater toleration of individuality is permitted, but women have to do more work to conform, squeezing out any possibility for 'the person' to emerge.

Paradoxically, since the inception of the RAE, previously marginalised work has been re-valued in purely financial terms. This has allowed feminist and queer scholars to pursue a critique, but disciplined by the limits imposed by the funding structures. Inoue (2007: 82) offers this challenge:

The concern for critical theory is that neoliberalism as an art of (self) government threatens to align seamlessly with the individual's ethical practice of self-mastery and self-autonomy within feminist and liberal-democratic thinking, thus evacuating the critical edge of the latter.

We see the hollowness of what is offered by the neoliberal regime when we note that within the same time period of RAE/REF culture, there has been little progress in gender equality as measured by the proportion of female scholars to male in the UK with a

preponderance of women still clustering in lower grade and part-time jobs. ${ }^{3}$ Internally published statistics from external consultants in an equal pay audit in 2009 show an average pay gap of $10.32 \%$ between male and female employees at a large East Midlands University. Primarily, the majority of principal lecturer/ readers are male. These are just some of the issues relating to neoliberalism, higher education, gender and sexuality which are explored throughout the contributions to this special issue.

\section{Some ways forward and possibilities of resistance}

Many scholars of neoliberalism note that it is an inherently unstable system full of tensions and contradictions. This, at least in theory, should allow for the possibility of resistance. In 
fact, Harvey (2005: 186) claims 'the desire for an alternative to neoliberalization is abundantly in evidence'. Chiapello and Fairclough (2002) write that new discourses may come into the institution and be enacted (by management), but in the case of universities, the discourses have not been absorbed by academics (2002: 195). Lynch (2006) calls for academics to start building a counter-hegemonic discourse grounded in principles of democracy and equality. Some of our contributors, but not all, seem to be optimistic that we can build resistance to the pervasiveness of neoliberal discourse and thereby oppose gender and sexuality inequality that it entails.

Johnson (this issue) argues that neoliberalism has been around for a while, but we are now seeing an intensification of its embrace. While noting Polyani's (1957) view that economies are embedded in cultures, he makes the point that these dominant models never wholly expunge other trajectories. The fact that neoliberalism is not all-encompassing is what makes it possible to critique the structures which attempt to govern and regulate us in the academy. Furthermore, as much as these other perspectives exist alongside the dominant ones, there remains the possibility of looking back to a previous existence and perhaps re-installing that ethos. This point is echoed by Lynch (2006: 10) who claims 'while the neo-liberal code is dominant, there are alternative narratives, narratives of equality and inclusion that challenge the prevailing orthodoxies.'

Canaan suggests we are living at a point which presents a unique opportunity for presenting an alternative. And if that is so, then U.K. Vice Chancellors' current fashion for 'shock-doctrine' offers a moment of vulnerability in which a resistance to its discursive regulation can be mounted. Canaan offers two thinkers who allow for possibilities outside of the crisis of economic rationalism and regulation: Bourdieu and Butler. Both question 
the fixity of the dominant and the supposed natural. Butler recognises that norms are only legitimated by constant citation, and we can choose to stop the repetition. The very instability of the academy's processes and structures renders it vulnerable to a revoking of neoliberal practice. In a similar vein, Johnson cites Williams' argument that the hegemonic provides the basis for the counter-hegemonic, and that the 'residual' can still be reactivated. There is also the 'emergent' - that which a dominant social order represses or fails to recognize. This is the most crucial tool for dealing with the dominant and for allowing subversion, as the emergent seeks new forms or reworks old practices.

What we learn perhaps from all of the papers in this special issue is that we as academics do not transform institutions by assimilating neoliberal discourses and practices. What we need to do instead is to challenge these discourses and practices and, in the case of $\mathrm{HE}$, defend our own values of equality and democracy from strategic assault.

That critique is possible, is the overall force of these papers. This critique must take place explicitly, through fora such as this, but also 'off stage' in staffrooms, cloakrooms and in classrooms. David sets the scene for this critique with an assessment of how far the project of transforming and diversifying the academy has reached. She writes of the limits and challenges posed by 'academic capitalism', defined by Slaughter and Leslie (1997) as the imposition of markets and market-like behaviours on universities. Within their walls, and within this paradigm, academics are required to harness their own production to their own benefit, to that of their university, and, more recently, to the short-term requirements of their national economy. This issue asks to what extent this experience forms our subjectivity, our experience and our expectations of ourselves, our pedagogy and of our students. 
Canaan calls for 'scholarship with commitment' while Johnson wishes to reject the individualism of neoliberalism, and instead urges scholars to work collaboratively on projects which are critical and resistant to neoliberal governance. We hope that this collaborative project adds its voice to the challenge.

\footnotetext{
${ }^{1}$ This process is likely to be known as the Research Excellence Framework in future.

${ }^{2}$ Duggan discusses the famous closure of the Women's Studies programme at SUNY New Paltz in her 2003 book.

${ }^{3}$ Figures from the Higher Education Statistics Agency (cited in Lipsett 2008) show that women were 42.3\% of academic staff in 2006-7.
} 


\section{References}

Baxter, J. (2003) Positioning Gender in Discourse: A Feminist Methodology, Basingstoke:

Palgrave.

Butler, J. (1990) Gender Trouble: Feminism and the Subversion of Identity, New York:

Routledge

Butler, J. (2004) Undoing Gender, New York: Routledge.

Canaan, J. (2005) 'Developing a pedagogy of critical hope', Learning and Teaching in the Social Sciences 2, no. 3: 159-174.

Canaan, J. and Shumar, W. (eds) (2008) Structure and Agency in the Neoliberal

University, London: Routledge.

Chiapello, E. and Fairclough, N. (2002) 'Understanding the new management ideology: a transdisciplinary contribution from critical discourse analysis and new sociology of capitalism', Discourse and Society 12, no. 2: 185-208.

Coates, J. (1996) Women Talk: Conversation between Women Friends, Oxford: Blackwell.

Coates, J. (2003) Men Talk: Stories in the Making of Masculinities, Oxford: Blackwell.

Connell, R. (1995) Masculinities, Cambridge: Polity Press.

Davies, B. and Bendix Peterson, E. (2005) 'Neo-liberal discourse in the academy: The forestalling of (collective) resistance', Learning and Teaching in the Social Sciences 2, no. 2: 77-98.

Davies, B. and Saltmarsh, S. (2007) 'Gender economies: Literacy and the gendered production of neo-liberal subjectivities', Gender and Education 19 no. 1: 1-20. 
Duggan, L. (2003) The Twilight of Equality: Neoliberalism, Cultural politics and the Attack on Democracy, Boston, MA: Beacon Press.

Esler, P. (2008) 'A new economy for knowledge, The Guardian 13 August.

Evans, M. (2005) Killing Thinking: The Death of the Universities, London: Continuum. Fairclough, N. (1995) Critical Discourse Analysis, Harlow: Longman.

Gill, J. (2009) 'AUA Conference: V-C casts doubt on humanities funding', Times Higher Education Supplement, 16 April.

Goodall, H. L (1995) 'Work Hate', in R. K. Whillock and D. Slayden (eds) Hate Speech. London: Sage, 80-121.

Harvey, D. (2005) A Brief History of Neoliberalism, Oxford: Oxford University Press Holmes, J. (2006) Gendered Talk at Work: Constructing Social Identity through Workplace Interaction, Oxford: Blackwell.

Inoue, M. (2007) 'Language and gender in an age of neoliberalism', Gender and Language 1, no. 1: 79-91.

Johnson, R. (2008) 'Afterword: University challenge: Neoliberal abstraction and being more concrete', in Canaan, J. and Shumar, W. (eds) Structure and Agency in the Neoliberal University, London: Routledge: 278 - 297.

Lipsett, A. (2008) 'More female academics working in universities', The Guardian, 28 February.

Lynch, K. (2006) 'Neo-liberalism and marketisation: The implications for higher education', European Educational Research Journal 5, no. 1: 1-17.

Molesworth, M.; Nixon, E. and Scullion, R. (eds). (2010 forthcoming) The Marketisation of Higher Education: The Student as Consumer. London: Routledge. 
Ong, A. (2006) Neoliberalism as Exception, Durham, NC: Duke University Press.

Polyani, K. (1957) The Great Transformations: The Political and Economic Origins of

Our Times, Boston: Beacon Press.

Rutherford, J. (2005) 'The market comes to higher education', Learning and Teaching in the Social Sciences 2, no. 1: 5-23.

Sauntson, H. and Morrish, L. (Forthcoming 2010) 'Vision, values and international excellence: The 'products' that university mission statements sell to students', in $\mathrm{M}$. Molesworth et al (eds) The Marketisation of Higher Education: The Student as Consumer, London: Routledge.

Slaughter, S. and Leslie, L. (1997) Academic Capitalism: Politics, Policies, and the Entrepreneurial University. Baltimore: Johns Hopkins University Press.

Sunderland, J. (2004) Gendered Discourses, Basingstoke: Palgrave.

Urciuoli, B. (2000) 'Strategically deployable shifters in college marketing, or just what do they mean by 'skills' and 'leadership' and 'multiculturalism'?', Language and Culture Symposium http://language-culture.binghamton.edu/symposia/6/index.html Accessed 16 June 2010 .

Welch, P. (2006) 'Feminist pedagogy revisited', Learning and Teaching in the Social Sciences 3, no. 3: 171-199.

Wright, S. (2004) 'Markets, corporations, consumers? New landscapes of higher education', Learning and Teaching in the Social Sciences 1, no. 2: 71-93. 